\title{
GAMBARAN UMUR, USIA KEHAMILAN, SERTA ALASAN IBU YANG MENGALAMI ABORTUS DI KECAMATAN CINEAM KABUPATEN TASIKMALAYA TAHUN 2010 S/D 2012
}

\author{
Oleh : \\ Purwati, S.KM. M.ARS
}

\begin{abstract}
A. Abstrak
Menurut laporan Program Kesehatan Ibu dan Anak di UPTD Puskesmas Cineam, pada tahun 2010 terjadi kasus kematian Bayi/ Balita sebanyak 31 orang, kematian Ibu 1 orang dan kasus Abortus 42 orang sedangkan tahun 2011 Kematian Bayi / Balita sebanyak 12 orang dan kejadian Abortus sebanyak 36 orang dengan rincian menurut jenisnya sebagai berikut: Spontan 30 kasus, Inkomplitus 4 kasus, Iminens 1 kasus dan propokatus 1 kasus. Sedangkan rincian menurut kelompok umur <20 tahun 11,11\%, umur 20-30 tahun 30,56\% dan umur >30 tahun sebesar 58,33\%. Tujuan penelitian adalah untuk memperoleh informasi tentang Gambaran umur, usia kehamilan, serta alasan ibu yang mengalami abortus di Kecamatan Cineam Kabupaten Tasikmalaya tahun 2010 s/d 2012.Manfaat penelitian ini adalah Untuk institusi (Puskesmas) sebagai bahan informasi tentang kejadian abortus yang terjadi di wilayah kerjanya. Selanjutnya dapat dijadikan bahan pertimbangan dalam perencanaan sebagai intervensi kegiatan penanganan kasus abortus dimasa yang akan datang.
\end{abstract}

Jenis penelitian yang digunakan kuantitatif dengan metoda deskriptif, dimana penulis akan memperoleh Gambaran umur, usia kehamilan, serta alasan ibu yang mengalami abortus di Kecamatan Cineam Kabupaten Tasikmalaya tahun 2010 s/d 2012. Populasi penelitian adalah ibu yang pernah mengalami abortus di wilayah kerja Puskesmas Kecamatan Cineam dengan mengambil data pada tahun 2010 sebanyak 17 orang dan data tahun 2011 sebanyak 15 orang. Teknik pengambilan sampel dengan cara total sampling karena semua anggota populasi menjadi sampel penelitian, yaitu sebanyak 32 orang. Data yang digunakan adalah data sekunder dengan mengacu pada laporan Puskesmas Cineam. Studi dokumentasi di digunakan untuk mendukung penelitian. Analisis data yang dilakukan pada penelitian ini menggunakan analisis univariat.

Berdasarkan hasil penelitian didapatkan bahwa Mayoritas umur ibu yang mengalami abortus yaitu kelompok umur antara kurang dari 20 tahun dan $\geq 30$ tahun yaitu sebanyak 26 orang (81,2 \%), Mayoritas usia kehamilan yang mengalami abortus sebagian besar termasuk usia kehamilan muda yaitu sebanyak 30 orang (93,8\%), Mayoritas alasan tindakan aborsi adalah tepat ( secara alamiah dengan indikasi medis ) hanya $28,1 \%$.

Keguguran dapat terjadi secara spontan atau buatan/ disengaja. Aborsi spontan biasanya terjadi sebelum kehamilan berusia 12 minggu (3 bulan) sedangkan aborsi buatan yang dilakukan setelah kehamilan 12 minggu dapat mengancam jiwa ibu.Saran yang direkomendasikan adalah puskesmas harus lebih meningkatkan pemahaman masyarakat tentang kesehatan reproduksi khususnya sehingga dapat mempersiapkan kehamilan yang sehat serta pihak puskesmas mampu mencari faktor utama penyebab kejadian abortus pada ibu hamil sehingga dapat dijadikan dasar dalam penyusunan perencanaan kegiatan pencegahan abortus pada ibu hamil melalui progran Kesehatan Ibu dan Anak (KIA)

Kata Kunci : Abortus, Umur ibu, usia kehamilan, alasan 


\section{B. Latar belakang}

Angka Kematian lbu (AKI) di Indonesia masih tinggi. Menurut Survei Demografi dan Kesehatan Indonesia (SDKI) 2007, AKI di Indonesia adalah 228 per 100.000 kelahiran hidup. Ada 3 penyebab klasik kematian ibu yaitu perdarahan, keracunan kehamilan dan infeksi. Menurut Organisasi Kesehatan Dunia (WHO) 15-50\% kematian ibu disebabkan oleh abortus. Abortus berdampak perdarahan atau infeksi yang dapat menyebabkan kematian.

Penyebab utama kematian ibu adalah pendarahan post partum yang di perkirakan mencapai sekitar 40-50 \%, sepsis dan eklamsia, disamping partus lama dan abortus terkomplikasi. Salah satu penyebab kematian adalah abortus, dimana abortus adalah adalah keluarnya hasil pembuahan (janin) sebelum kehamilan berumur 20 minggu. Keguguran dapat terjadi secara spontan atau buatan/disengaja. Aborsi spontan biasanya terjadi sebelum kehamilan berumur 12 minggu (3 bulan) sedangkan aborsi buatan yang dilakukan setelah kehamilan 12 minggu dapat mengancam jiwa ibu.

Aborsi telah dilakukan oleh 2,3 juta perempuan. Diperkirakan diseluruh dunia setiap tahun terjadi 40-70 aborsi per 100 wanita usia produktif. Umur ibu merupakan salah satu faktor resiko terjadinya abortus, dalam kurun reproduksi sehat dikenal bahwa usia aman dalam kehamilan, persalinan dan kelahiran yaitu 20-35 tahun. (Wheeler L, 2004).

Menurut laporan Program

Kesehatan Ibu dan Anak di UPTD Puskesmas Cineam, pada tahun 2010 terjadi kasus kematian Bayi/ Balita sebanyak 31 orang, kematian Ibu 1 orang dan kasus Abortus 42 orang sedangkan tahun 2011 Kematian Bayi / Balita sebanyak 12 orang dan kejadian Abortus sebanyak 36 orang dengan rincian menurut jenisnya sebagai berikut: Spontan
30 kasus, Inkomplitus 4 kasus, Iminens 1 kasus dan propokatus 1 kasus. Sedangkan rincian menurut kelompok umur $<20$ tahun $11,11 \%$, umur $20-30$ tahun $30,56 \%$ dan umur $>30$ tahun sebesar 58,33\%.

Berdasarkan data tersebut diatas, penulis merasa perlu untuk melakukuan penelitian tentang "Gambaran umur, usia kehamilan, serta alasan ibu yang mengalami abortus di Kecamatan Cineam Kabupaten Tasikmalaya tahun 2010 s/d 2012”

Tujuan penelitian adalah untuk memperoleh informasi tentang Gambaran umur, usia kehamilan, serta alasan ibu yang mengalami abortus di Kecamatan Cineam Kabupaten Tasikmalaya tahun 2010 s/d 2012. Manfaat penelitian ini adalah Untuk institusi (Puskesmas) sebagai bahan informasi tentang kejadian abortus yang terjadi di wilayah kerjanya. Selanjutnya dapat dijadikan bahan pertimbangan dalam perencanaan sebagai intervensi kegiatan penanganan kasus abortus dimasa yang akan datang.

\section{Metode}

Jenis penelitian yang digunakan kuantitatif dengan metoda deskriptif, dimana penulis akan memperoleh Gambaran umur, usia kehamilan, serta alasan ibu yang mengalami abortus di Kecamatan Cineam Kabupaten Tasikmalaya tahun 2010 s/d 2012. Populasi penelitian adalah ibu yang pernah mengalami abortus di wilayah kerja Puskesmas Kecamatan Cineam dengan mengambil data pada tahun 2010 sebanyak 17 orang dan data tahun 2011 sebanyak 15 orang. Teknik pengambilan sampel dengan cara total sampling karena semua anggota populasi menjadi sampel penelitian, yaitu sebanyak 32 orang.

Data yang digunakan adalah data sekunder dengan mengacu pada laporan Puskesmas Cineam. Studi dokumentasi di digunakan untuk mendukung penelitian. 
Dilakukan dengan membaca, menelaah dan mempelajari dokumen yang berkaitan dengan permasalahan seperti laporan KIA.

Pengolahan data dilakukan melalui tahapan sebagai berikut:

1). Editing, merupakan kegiatan untuk melakukan pengecekan isian formulir atau kuesioner apakah jawaban yang ada sudah lengkap dan jelas.

2). Coding, merupakan kegiatan perubahan data berbentuk huruf menjadi data berbentuk angka atau bilangan.

3). Proccessing, setelah semua kuesioner terisi penuh dan benar serta telah melalui tahapan pengkodean, maka langkah selanjutnya adalah memproses data agar dapat dianalisis. Pemrosesan data

\section{Hasil penelitian}

\section{Gambaran Umur Responden}

Karakteristik individu berdasarkan umur yang pernah mengalami keguguran/abortus sebagai responden penelitian di Kecamatan Cineam Kabupaten Tasikmalaya dapat dilihat pada tabel berikut :

\section{Karakteristik individu berdasarkan umur responden :}

\begin{tabular}{|c|c|c|c|}
\hline No & $\begin{array}{c}\text { Kelompok } \\
\text { Umur }\end{array}$ & Jumlah & $\boldsymbol{\%}$ \\
\hline 1 & $<20$ tahun & 1 & 3,1 \\
2 & $20-30$ tahun & 6 & 18,8 \\
3 & $>30$ tahun & 25 & 78,1 \\
\hline & Jumlah & $\mathbf{3 2}$ & $\mathbf{1 0 0}$ \\
\hline
\end{tabular}

Berdasarkan tabel 5.5 Umur yang termasuk beresiko untuk melaksanakan tindakan abortus yaitu kelompok umur antara kurang dari 20 tahun dan $\geq 30$ tahun yaitu sebanyak 26 orang $(81,2$ $\%)$ sedangkan kelompok umur yang tidak beresiko untuk melaksanakan tindakan aborsi yaitu sebanyak 6 orang $(18,8 \%)$. dilakukan dengan cara meng-entry data dari kuesioner ke paket program komputer. Program yang digunakan untuk pemrosesan data adalah program Microsoft Exel dan SPSS versi 13,0.

4). Cleaning, merupakan kegiatan pengecekan kembali data yang sudah dientry apakah ada kesalahan atau tidak.

Analisis data yang dilakukan pada penelitian ini menggunakan analisis univariat.Analisi univariat dilakukan untuk mendeskripsikan masing-masing variabel yang digunakan dalam penelitian ini dengan melihat distribusi frekuensi dengan ukuran prosentase/ proporsi pada setiap variabel yang diteliti.

\section{Gambaran Usia kehamilan responden}

Sedangkan untuk mengetahui gambaran karakteristik individu berdasarkan usia kehamilan responden pada waktu kejadian abortus di Kecamatan Cineam Kabupaten Tasikmalaya dapat dilihat pada tabel berikut ini :

\section{Karakteristik responden berdasarkan usia kehamilan pada waktu kejadian abortus}

\begin{tabular}{|c|c|c|c|}
\hline No & $\begin{array}{c}\text { Usia } \\
\text { Kehami } \\
\text { lan }\end{array}$ & Jumlah & $\%$ \\
\hline 1 & Muda & 30 & 93,8 \\
2 & Tua & 2 & 6,2 \\
\hline & Jumlah & 32 & 100 \\
\hline
\end{tabular}

Berdasarkan tabel 5.6 diperoleh gambaran bahwa usia kehamilan responden pada waktu kejadian abortus sebagian besar termasuk usia kehamilan muda yaitu sebanyak 30 orang $(93,8 \%)$ dan yang termasuk usia kehamilan tua hanya 2 orang $(6,2 \%)$. 


\section{Gambaran alasan abortus responden}

Sedangkan mengenai karakteristik individu berdasarkan alasan melaksanakan tindakan aborsi dapat di lihat pada tabel berikut :

Karakteristik individu berdasarkan indikasi

\begin{tabular}{|c|c|c|c|}
\hline No & Alasan & Jumlah & \% \\
\hline 1 & Tidak Tepat & 23 & 71,9 \\
2 & Tepat & 9 & 28,1 \\
\hline & Jumlah & 32 & 100 \\
& & & \\
\hline
\end{tabular}

\section{E. Pembahasan}

Berdasarkan hasil penelitian yang dilakukan terhadap ibu-ibu yang pernah mangalami tindakan aborsi di Wilayah Kecamatan Cineam, ternyata sebagian besar termasuk usia yang termasuk kelompok resiko ( < dari 20 tahun atau > dari 30 tahun ) yaitu sebanyak 26 orang $(81,2 \%)$ dan hanya sebagian kecil yaitu sebanyak 6 orang $(18,8 \%)$ dari mereka yang termasuk kelompok tidak resiko/aman untuk hamil dan melahirkan. Berdasarkan hasil penelitian terhadap 32 orang responden dengan menggunakan metoda konseling ternyata sebagian besar mengatakan bahwa aborsi yang terjadi merupakan tindakan aborsi provokatus atau disengaja yaitu sebanyak 21 orang $(65,63 \%)$ dan hanya 11 orang $(34,37 \%)$ abortus spontan atau terjadi secara alamiah.

Menurut Cunningham (1995) frekuensi abortus bertambah dari $12 \%$ pada wanita yang berusia kurang dari 20 tahun, menjadi $26 \%$ pada wanita berumur diatas 40 tahun. Pada usia diatas 35 tahun telah terjadi sedikit penurunan denyut jantung yang disebabkan oleh berkembangnya kontraksi miokardium sehingga sirkulasi dan pengambilan $\mathrm{O}_{2}$ oleh darah di paru-paru juga mengalami penurunan, ditambah lagi
Dari tabel 5.10 diperoleh gambaran bahwa responden yang melaksanakan tindakan aborsi dengan alasan yang tepat (secara alamiah dengan indikasi medis) hanya $28,1 \%$, lebih rendah dibandingkan dengan yang melaksanakan tindakan aborsi dengan alasan tidak tepat $(71,9 \%)$ terdapat berbagai alasan yaitu ekonomi, umur, sudah tidak menginginkan anak lagi, kegagalan kontrasepsi, tekanan orang tua dan suami.

dengan peningkatan tekanan darah dan penyakit lainnya yang melemahkan kondisi ibu, sehingga mengganggu sirkulasi darah ibu ke janin. Hal ini akan mengganggu pertumbuhan dan perkembangan hasil konsepsi, dimana hasil konsepsi tidak dapat berimplantasi secara maksimal yang mengakibatkan kematian atau lepasnya sebagian atau seluruh dari hasil konsepsi dari tempat implantasi. bagian yang terlepas ini dianggap benda asing oleh uterus sehingga uterus berusaha untuk mengeluarkannya dengan cara berkontraksi (Multazamiah, 2003).

Kehamilan bisa jadi dambaan, tetapi mungkin juga dianggap malapetaka apabila perempuan itu sendiri tidak/atau belum menginginkan kelahiran anak. Sebab-sebab seorang perempuan mengalami kahamilan yang tidak diinginkan (KTD) sangatlah bermacammacam. KTD dapat menimpa pasangan yang belum menikah ataupun yang yang sudah menikah. Sebagian dari mereka menyelesaikan KTD-nya dengan pengguguran kandungan (aborsi).

Karena kondisi hukum belum melegalkan tindakan pengguguran kandungan, sehingga masih banyak yang melakukannya dengan cara yang tidak aman yaitu dengan cara minum ramuan 
atau obat telat datang bulan atau obat tradisional yang diketahui dari tetangga atau keluarganya walaupun dengan resiko yang cukup besar. Usia kehamilan pada kejadian abortus bisa mengindikasikan seseorang melakukan tindakannya secara alamiah (spontan) ataupun disengaja seperti pada salah satu yang berjudul Komunikasi, Informasi, Edukasi (KIE) Kesehatan Reproduksi tahun 2002 bahwa keguguran atau aborsi adalah keluarnya hasil pembuahan (janin) sebelum kehamilan berumur 20 minggu.

Keguguran dapat terjadi secara spontan atau buatan/disengaja. Aborsi spontan biasanya terjadi sebelum kehamilan berusia 12 minggu (3 bulan) sedangkan aborsi buatan yang dilakukan setelah kehamilan 12 minggu dapat mengancam jiwa ibu.

Hasil penelitian menunjukan bahwa dari 32 responden ada sebanyak 93,8\% termasuk usia kehamilan muda ( usia kehamilan < dari 3 bulan ) dan hanya $6,2 \%$ termasuk usia kehamilan tua (diatas usia kandungan 3bulan ). Apabila dibandingkan dengan hasil analisa yang telah dilakukan ternyata kasus atau kejadian aborsi spontan atau dengan alasan yang tepat hanya sebesar $28,1 \%$ sedangkan yang melaksanakan tindakan aborsi dengan alasan yang tidak tepat sebesar $71,9 \%$. Sebagai justifikasi kedua jenis data hasil penelitian didapatkan bahwa tindakan aborsi secara sengaja dilakukan pada usia kehamilan muda

Sebagai upaya tindak lanjut dalam rangka menekan angka kejadian tindakan aborsi di Kecamatan Cineam dapat dilakukan kegiatan diantaranya dengan pembentukan jejaring informasi. Jejaring informasi ini berasal dari level masyarakat paling bawah yang dalam prakteknya melibatkan kader dasawisma yang akan dapat bekerja secara efektif dan efisien karena keberadaannya lebih dekat dengan masyarakat. Jejaring informasi ini bertujuan mencari informasi dan melaporkan kejadian kehamilan muda secara berjenjang kepada aparat yang ada di atasnya yaitu dari mulai kader dasawisma, ketua RT, ketua RW/ kepala Dusun, Desa/bidan desa dan Kecamatan/Puskesmas. Berdasarkan informasi tersebut akan diketahui data kehamilan muda yang selanjutnya bisa dijadikan dasar untuk pelaksanaan kegiatan pemeriksaan kehamilan oleh bidan (peningkatan pemeriksaan bumil) dan sekaligus memberikan motivasi agar kehamilan tersebut bisa berlangsung sampai melahirkan walaupun kehamilannya tidak diinginkan.

Dilihat dari segi alasan yang di kemukakan responden waktu wawancara dengan peneliti ternyata alasan yang tidak tepat dalam melaksanakan tindakan aborsi jauh lebih besar (71,9\%) dibandingkan dengan yang melaksanakan tindakan aborsi dengan alasan yang tepat $(28,1 \%)$. Tindakan pengguguran kandungan hanya bisa dilaksanakan apabila mempunyai alasan yang tepat baik itu terjadi secara alamiah atau dengan alasan dengan indikasi medis. Pengguguran kandungan secara tradisional mempunyai resiko yang sangat tinggi, karena dapat menyebabkan kerusakan rahim, infeksi rahim, infertilitas, perdarahan, komplikasi, bahkan kematian. Terlebih lagi secara hukum pengguguran kandungan dilarang keras (ilegal) dengan alasan apapun kecuali untuk menyelamatkan jiwa ibu dan si janin (Undang-Undang Kesehatan No.23 tahun 1992).

Dengan besarnya prosentase alasan tindakan aborsi yang tidak tepat, tentu menjadi masalah kesehatan di Kecamatan Cineam. Hal ini karena melanggar kode etik profesi/ Undang-Undang Kesehatan atau peraturan yang berlaku. Bila kondisi ini dibiarkan akan berdampak pada kesehatan masyarakat terutama angka kematian ibu. Selain itu juga akan semakin berkembangnya praktek-praktek tindakan aborsi ilegal, baik yang dilakukan oleh tenaga kesehatan atau non 
tenaga kesehatan. Hasil penggalian data lebih lanjut mengenai alasan tindakan abortus, diantaranya adalah umur yang sudah tua, tidak menginginkan memiliki anak lagi, alasan ekonomi, akibat kegagalan alat kontrasepsi, karena tekanan suami dan lain-lain.

\section{F. Simpulan dan saran}

Berdasarkan hasil penelitian dapat disimpulkan :

1. Mayoritas umur ibu yang mengalami abortus yaitu kelompok umur antara kurang dari 20 tahun dan $\geq 30$ tahun yaitu sebanyak 26 orang $(81,2 \%)$.

2. Mayoritas usia kehamilan yang mengalami abortus sebagian besar termasuk usia kehamilan muda yaitu

\section{G. Referensi}

Bobak, Lowdermilk, Jensen. (2004). Buku Ajar Keperawatan maternitas. Edisi 4 Alih bahasa oleh Maria A. Wijayarini dan Peter I Anugrah. Jakarta: Penerbit

Buku Kedokteran ECG.

Cunningham. (2005). Obstetri Williams. Jakarta : RCG

Depkes R1. 2003- Inclikator Indonesia Sehat 2010. Jakarta

Handayani, D. (2006). Abortus, Cari Penyebab.

http://www.jawapos.com/fndeks

hnp://strategihr.insannusantara.com/2010/0

4/upah-minimum-regional-2011-

berapayah/Kementerian Tenaga Kerja dan

Transmigrasi (Kemenakertrans)

Ida Bagus Gede Manuaba. (1998). Ilmu

Kebidanan Penyakit Kandungan dan

Keluarga Berencana Untuk

Pendidikan Bidan, Edisi I. Jakarta : EGC

Martaadisoebrata, D.(1982). Obstetri Sosial. Bagian obstetri dan Ginekologi Fakultas Kedokteran Universitas Padjadjaran Bandung. Bandung. ElstarOffset. sebanyak 30 orang $(93,8 \%)$.

3. Mayoritas alasan tindakan aborsi adalah tepat ( secara alamiah dengan indikasi medis ) hanya $28,1 \%$

Saran yang direkomendasikan adalah puskesmas harus lebih meningkatkan pemahaman masyarakat tentang kesehatan reproduksi khususnya sehingga dapat mempersiapkan kehamilan yang sehat serta pihak puskesmas mampu mencari faktor utama penyebab kejadian abortus pada ibu hamil sehingga dapat dijadikan dasar dalam penyusunan perencanaan kegiatan pencegahan abortus pada ibu hamil melalui progran Kesehatan Ibu dan Anak (KIA)

Multazamiah, (2003). Hubungan Usia Ibu

> 35 Tahun Dengan kejadian Abortus di Ruangan C, (Kebidanan) RSUD Dr. M. Yunus Bengkulu, Tahun 2003, Skripsi Akademi Kebidanan : Poltekkes Bengkulu

Notoatmodjo, S. (2002). Metode Penelitian Kesehatan. Jakarta: Rineka Cipta

Saifudin. (2002). Peranan Kesehatan Maternal dan Neonatal. Jakarta : Yayasan Bina Pustaka.

Sarwono. (1999). Ilmu Kebidanan. Jakarta: Yayasan Bina Pustaka Sarwono.

Sarwono. (2008). Ilmu Kebidanan. Jakarta : Yayasan Bina Pustaka, Sarwono.

Sulaeman. (2005). Ilmu Kesehatan Reproduksi : Obstetri Patologi. Edisi 2. Jakarta EGC

Yahya dan Ngalimun. 2004

Profesionalisme Sistem Pelayanan 


\title{
GAMBARAN FAKTOR-FAKTOR PENYEBAB BAYI BERAT LAHIR RENDAH (BBLR) DI WILAYAH KERJA UPTD PUSKESMAS SINGAPARNA KABUPATEN TASIKMALAYA TAHUN 2013
}

Oleh:

\author{
Erwina Sumartini, S.ST
}

\begin{abstract}
A. Abstrak
Menurut data Puskesmas kejadian BBLR pada tahun 2012 berjumlah 74 Bayi dan tahun 2013 berjumlah 58 bayi. BBLR juga menjadi penyebab tertinggi dari kematian bayi di Puskesmas Singaparna, pada tahun 2013 kematian bayi akibat BBLR sebanyak 7 bayi (33,33\%) dan pada tahun 2013 sebanyak 2 bayi (14,28\%).Secara umum faktor-faktor yang berhubungan dengan kejadian BBLR diantaranya : 1) faktor ibu yaitu penyakit yang diderita ibu, komplikasi kehamilan, umur ibu, paritas, jarak kehamilan, riwayat BBLR, gizi ibu selama hamil, sosial ekonomi dan pengawasan antenatal yang kurang. 2) faktor janin yaitu : kelainan kromosom, infeksi janin kronik, disautosomia familia, radiasi, kehamilan ganda/kembar dan aplasia pancreas.

Rancangan penelitian yang digunakan adalah jenis kuantitatif dengan metode penelitian deskriptif. Populasi penelitain adalah seluruh ibu yang melahirkan bayi baru lahir dengan BBLR sebanyak 71 orang. Analisis yang digunakan adalah analisis univariat.

Berdasarkan hasil penelitian menunjukan bahwa BBLR di wilayah kerja UPTD Puskesmas Singaparna Kabupaten Tasikmalaya sebagian besar dilahirkan oleh ibu dengan usia 20-30 tahun (70.42\%) dan paritas multipara (53.52\%)sebagian besar dilahirkan oleh ibu dengan status gizi baik (tidak KEK $84.51 \%$ ) sebagian besar dilahirkan oleh ibu yang tidak mempunyai komplikasi kehamilan (59.15\%) dan tidak mempunyai penyakit saat hamil $(90.14 \%)$ dan tidak mengalami hamil kembar (90.14\%).

Berdasarkan hasil penelitian tersebut disimpulkan bahwa usia 20-30 tahun dan paritas multipara merupakan penyebab terbanyak kasus BBLR di wilayah kerja UPTD Puskesmas Singaparna Kabupaten Tasikmalaya Tahun 2013. Saran bagi pihak Puskesmas adalah melakukan upaya untuk memotivasi setiap pasangan usia subur untuk mengatur jarak kehamilan di usia reproduksi dan lebih meningkatkan kualitas asuhan antenatal kepada seluruh ibu hamil dengan atau tanpa risiko kehamilan dengan menekankan asupan nutrisi pada ibu hamil dan mendeteksi sesegera mungkin setiap komplikasi yang terjadi pada ibu hamil, serta melakukan penanganan intensif terhadap penyakit yang diderita ibu saat hamil.
\end{abstract}

Kata Kunci : BBLR, usia, paritas, gizi ibu hamil, komplikasi kehamilan, penyakit saat hamil. 